\title{
Spatial representations and policy implications of industrial co- agglomerations, a case study of Beijing
}

\author{
Zhenshan Yang a, Tao Song ${ }^{a}$ *, Teresa Chahine ${ }^{b}$ \\ ${ }^{a}$ Key Lab of Regional Sustainable Development and Modelling, Institute of Geographical Sciences and Natural Resources Research, Chinese Academy of \\ Sciences, Beijing, 100101, China \\ ${ }^{\mathrm{b}}$ Harvard School of Public Health, Harvard University, Landmark Center, 4th Floor West, 401 Park Drive, Boston, MA, 02115, USA
}

\section{A R T I C L E I N F O}

\section{Article history:}

Received 20 July 2015

Received in revised form

12 January 2016

Accepted 20 February 2016

Available online 2 March 2016

\section{Keywords:}

Industrial co-agglomerations

Regional growth

Urban planning

Spatial structure

Exploratory spatial data analysis

Input-output method

China

\begin{abstract}
A B S T R A C T
Industrial parks have been tested in various regions around the world, in attempt to foster innovation and fuel economic growth. Despite the importance of industry co-agglomerations in regional growth, few studies examine them in regional geographic space. This paper combines exploratory spatial data analysis and input-output method to explore the spatial pattern of key industrial co-agglomerations in Beijing, which is illustrated by location, function, frequency, spatial hierarchy and spacing. The results contribute to linking abstract economic and actual geographical spaces in urban and regional growth, enabling urban and regional planners to judge and evaluate planning initiatives before and after implementation. The failure of sub-center plans and risks of industrial parks schemes in Beijing are addressed. By considering industrial input-output relations including environmental and human resources, urban planners can optimize the development of such co-agglomerations to foster sustainable urban development.
\end{abstract}

(c) 2016 Elsevier Ltd. All rights reserved.

\section{Introduction}

In the fields of urban and regional planning, a primary focus has been given to identify and understand co-agglomerations of industries. Applications of this field of study include monitoring disequilibrium and domination during economic development, cultivating chances of cooperation and rivalry, creating milieu for shaping industrial competitiveness, and stimulating technological innovation (Belussi \& Caldari, 2009; Funderburg \& Boarnet, 2008; Mota \& de Castro, 2004; Porter, 1998a; Rigby and Essletzbichler, 2002; Steinle and Schiele, 2002). While it is has been acknowledged that a group of related industries are co-located or geographically proximate (LaFountain, 2005), few studies have examined the spatial pattern of the co-agglomeration of industries to inform the above applications (Arbia, Espa, Giuliani, \& Mazzitelli, 2010; Arbia, Espa, \& Quah, 2008). As urban and regional economies grow, the spatial distribution and geographical co-agglomeration of industries may not necessarily follow the same patterns. To date,

\footnotetext{
* Corresponding author.

E-mail addresses: yangzs@igsnrr.ac.cn (Z. Yang), Songtaosongtao77@163.com (T. Song), tchahine@hsph.harvard.edu (T. Chahine).
}

planning efforts to match the geographic and economic clustering of industries have been limited, although there are various industrial park schemes. To improve the evaluation of urban planning implications and inform future policy-making, an analysis of the spatial co-agglomeration of industries as it relates to economic patterns is required. Such an analysis will inform the understanding and optimization of such schemes and other planning options, including how to optimize industrial input-output relations governing environmental and human resources.

The spatial pattern of the co-agglomeration of industries is of great importance to regional studies and urban planning practices (Isard, 1956; Rigby and Essletzbichler, 2002). It is the projection of the economic structure onto the geographical space, as a spatial response to the economic attempts or endeavors associated with the co-agglomerated industries. In practice, this effort can help subjective planning measures more closely reflect market reality. It is not a new but rather an ongoing criticism that planning or policy decisions do not adequately respond to market forces, and that is the main reason of many failed and prematurely abandoned planning strategies (Friedmann, 2005; Souza and Silva, 2011). Coagglomerated industries in economic space can translate into a variety of structures in geographical space, and vice versa. In their own right the two structures of economic and geographical spaces 
may differ, and this may lead to loss of efficiency in operation (Neuman \& Hull, 2009). Capturing these differences is critical in planning making process.

Among various constructs of industrial relationships, horizontal and complementary relations seem a more important coagglomeration type to economic development and their spatial representation is more meaningful for policy analysis. Compared to the traditional argument for supply chains or vertical linkages from suppliers to producers and consumers as their basic input data (McDonald, Huang, Tsagdis, \& Tuselmann, 2007; Oosterhaven, Eding, \& Stelder, 2001), a growing number of studies have claimed that horizontal and complementary relations are more important at a city and regional level, for facilitating and stimulating competition, cooperation and innovation, as a main source of regional economic growth (Li, 2012).

Porter (1998b, p. 199) points out that in the current knowledgedriven economic development, there is large potential in a group of industries with commonalities or complementariness. The industries with horizontal and complementary relations share similar demand or supply patterns, competing on market and resources or mutual attraction among suppliers of complementary products and/or among users of jointly supplied products (Hoover \& Giarratani, 1999). By stimulating competition on market and resources, horizontal and complementary relationships facilitate knowledge innovation and positive spillover effects, and such a role is perhaps no less than the specialisation process via supply chains (Hertog, Bergman, \& Remoe, 2001). Industries with horizontal and complementary relations also stimulate chances for new industries (Jacobs' externalities) and recently (Frenken, Oort, \& Verburg., 2007) used 'related variety' to show that a region specializing in a particular composition of complementary sectors will experience higher growth rates than a region specializing in noncomplementary sectors. However, these findings have yet to be incorporated into mainstream urban and regional planning efforts in a data driven manner.

This paper is interested in applying spatial data analysis to examine the urban spatial economy by decomposing the horizontal and complementary relations of industries, using empirical data from Beijing, a large city region with diversified economic activity (Xie, 2013; Yang, Cai, Ottens, \& Sliuzas, 2013). With the establishment of the free market and subsequent globalization, the government policymaking has shifted to promote regional growth with introducing sub-centers and industrial parks. Meanwhile, the industrial relationship has been dramatically re-shaped under free market economy under the global industrial value chain, and arguing that industry parks are a new production space in China $(\mathrm{Li}$, Bathelt, \& Wang, 2012, Wang and Wang, 1998; Yang et al., 2013). However, there is a big challenge for planners and policy makers to align these parks with market forces. Therefore, Beijing is a suitable case to study the co-agglomeration of industries, their spatial manifestations and how they inform regional economic planning against proposed planning measures.

We begin with a literature review to formulate a conceptual framework of the spatial representation of co-agglomeration of industries. Section 3 presents a methodology for examining the coagglomeration of industries in regional economic-spatial space, and Section 4 introduces the case of Beijing. We describe the results of the spatial manifestation of the key industrial co-agglomeration patterns in Section 5. A discussion of the understanding of this spatial manifestation and its policy implications follows in Section 6. Section 7 concludes with an evaluation of the value and limitations of this research.

\section{Industrial co-agglomerations and spatial representations}

Co-agglomerations of industries, the tendency of related industries to locate near to each other (Ellison \& Glaeser, 1997), share an important status in city and regional analyses and practices (Isard, 1956). They are often used to identify key groups of sectors for growth, sources of innovation and decomposing economic structure, widely appearing in regional and development theories, such as agglomeration economies, growth poles and industry clusters (Duranton \& Storper, 2006; Funderburg \& Boarnet, 2008; Giarratani, Gruver, \& Jackson, 2007).

Recent progress of spatial statistics and analysis makes it possible to revisit these classic urban and regional development theories. For instance, K-densities (Duranton \& Overman, 2005) and Ellison and Glaeser's index (Ellison \& Glaeser, 1997) are used to test geographic concentration and localization and of industries. There is also an attempt to examine the tendency of industries to be co-agglomerated and co-localised (Duranton \& Overman, 2008; Ellison, Glaeser, \& Kerr, 2007; Feser, Sweeney, \& Renski, 2005). However, most studies are applied at the national level, without pre-defined functional relationship that force the colocation of firms and industries.

The application of spatial statistics at city or regional scale, directed by functional relationships, is critical to understand in depth the key urban development concepts. Such an application could well inform urban planning policy. For example, Industry coagglomeration played an essential role in the concept of industrial clusters, which permeate worldwide, theorizing the practice of various special economic or industrial parks, which is usually taken as a main strive of cities and regions to empower their economy (Baissac, 2011; Cheng, van Oort, Geertman, \& Hooimeijer, 2013; Yang, Hao, \& Cai, 2015). However, this practice is not always successful, mainly due to failing in developing key industrial relationships (Rainer and Chen, 2006). The inconsistent economic and spatial initiatives hinder the aims of integrated economic and spatial development in the city. A mismatch between city subcenters and employment creation can waste a large amount of public resources and cause economic-spatial tensions (Song, Wang, Zhang, \& Peng, 2007).

A criticism also occurs in academic field. Although it is widely accepted that functional linkages and geographical proximity are essential for industrial growth, they have not been well linked, which is a thorny issue in current urban and regional analysis (Martin \& Sunley, 2003). The spatial dimension of industrial coagglomerations is quite often arbitrarily decided (Bergman \& Feser, 1999; Martin \& Sunley, 2003), and geographical proximity is not substantiated for understanding industrial organization.

Given the importance of co-agglomeration of industries to urban and regional development, this paper is interested in examining its spatial representation. That is addressed by the following concepts:

Function: represented by a group of interrelated industries (industry co-agglomeration) dedicated to particular economic activities:

Frequency: a limited number of locations are expected to be observed significantly at a regional scale because of different industrial attributes, uneven space, limited investment, and different favorable conditions for different economic activities.

Location: the place where an industry co-agglomeration is, as defined by the polarization on the geographical space of the economic poles formulated by the industry co-agglomeration.

Size and spacing: the land area/boundary of the spatial manifestation of the functionally interrelated industries and the distance of each location if not just one observed.

Spatial hierarchy: the place where the industry co- 
agglomeration is located significantly assumes importance; because of the public facilities and investment, the cost and returns of the economic activities are unlikely constant spatially. Some locations would be of more significant than others.

The concepts above are expected to help elaborate the spatial representation of the industry co-agglomeration, as well as investigate associated spatial configurations of the city region.

\section{Background: Beijing's urban economic growth strategy}

Beijing is the capital of China and has a leading role in the socioeconomic development of the country. After economic reforms of the 1980s, with strong local initiatives of privatization and introduction of western economic development models, the growth pole has been one of key elements of the city and regional strategies to boost economic development and adjust spatial structure. A typical move can be found in the 4th master city regional plan (Fig. 1). Each suburban district or town seat was proposed as a sub-center with the purpose of diluting the pressure of the main urban center, which is roughly overlapped by the 4th ring road (Xie, 2013). This strategy eventually failed due to the lack of economic attractions of the sub-centers (Yang et al., 2013).

Deeply affected by globalisation, the cluster development emerged in the early 1990s. The first well known cluster is perhaps the Information and Communication Technology (ICT), mainly located in Zhongguancun area, later designated as Zhongguancun Science Park (ZSP) in 1992, growing from the synergy with universities and academic institutes (Wang and Wang, 1998; Yu and Tong, 2003). ZSP demonstrated success in the last 20 years, generating substantial economic returns and employment positions. Afterwards, witnessing the miracle of the industry clusters, Beijing began to build up various industrial and business parks at

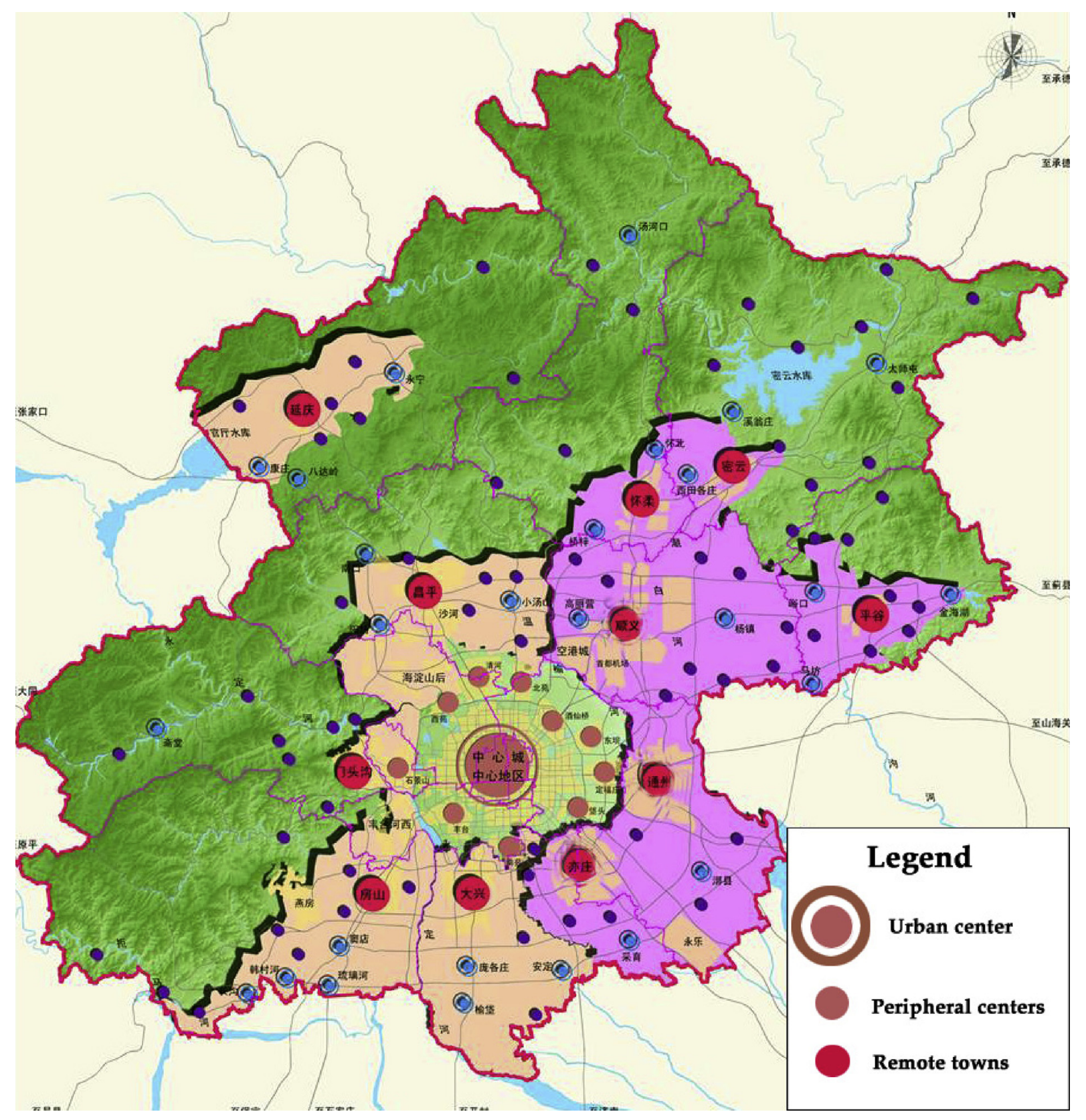

Fig. 1. Subcenters proposed in 1990s in Beijing. 
full strength with preferable regulations of land claim, taxation and even assistance in business marketing and promotion. Fig. 2 illustrates various parks in Beijing. Currently, there are 23 key parks at national or Beijing municipal levels, planned as a platform to encourage cluster-type development.

The fast growth of industry clusters has intrigued enthusiasm in testing various new development concepts in this area, such as innovative space, technological innovation, knowledge spillover, social network and institutional capacity (Li et al., 2012, Wang and Wang, 1998; Wei and Wang, 1993; Yu and Tong, 2003). The question remains as to how these economic success stories can link with overall regional spatial economic dynamics. Since not all planned clusters can succeed and the land abuse problem has been warned of for some industrial parks (Qiu, 1999), it is worthwhile evaluating planning initiates by actual development. In addition, it may be also useful to examine the linkage between different concepts such as growth poles and industrial clusters, identify their useful parts and overcome some shortcoming to improve further city and regional economic growth management.

\section{Methodology}

\subsection{Data and pre-process}

An Input-Output (I-O) table of industries was used for examining the industrial linkages from Beijing Statistic Bureau. Data for the test of the spatial clusters were retrieved from the firm-level record of registered business establishments in Beijing Industrial

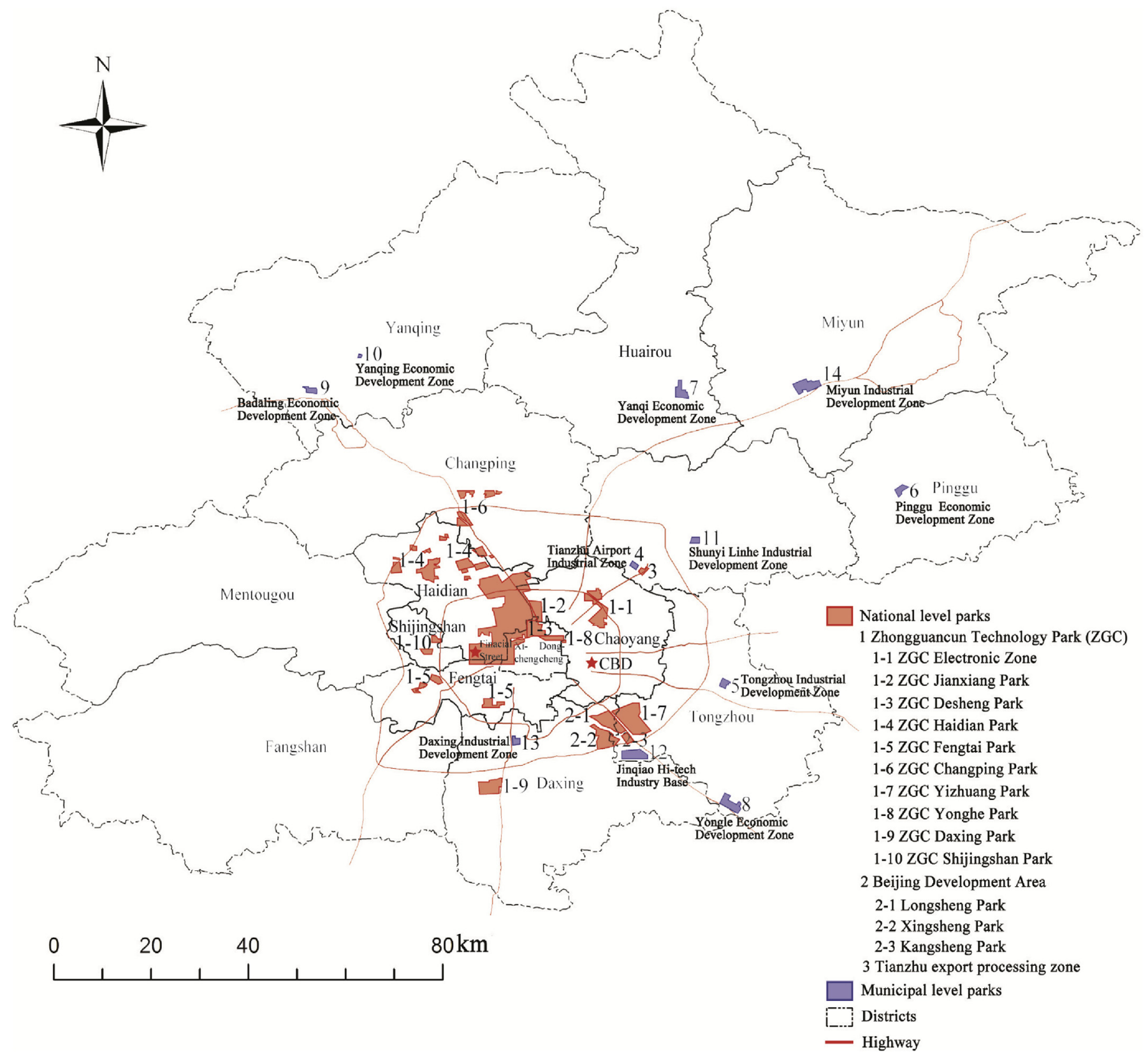

Fig. 2. Industrial and Business Parks in Beijing.

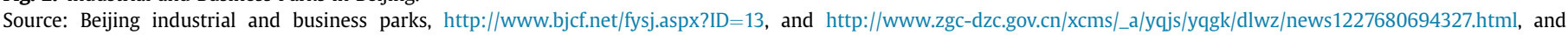
checking with documents of each park. 
and Commercial Bureau. Owing to the data availability, the $\mathrm{I}-\mathrm{O}$ table in 2002 and the firm records during 1998-2002 were recorded, with assumption that the functional relationship in 2002 contributed mainly by the nature of the firms that grew during the previous 5 years (5-year is normally a planning or policy period in China). The $\mathrm{I}-\mathrm{O}$ table records the trades of 79 manufacturing and 40 service sectors at 2-digit level of Standard Industrial Classification (SIC) in Beijing. The firm-level dataset records the established firms in that period with postcodes, employment statistics and the nature of employment.

Fig. 3 shows the basic spatial structure of Beijing, which covers $16,087 \mathrm{~km}^{2}$ with six inner urban districts, five outer urban districts and five exurban districts in the analyzed period. The spatial development of the urban area is also characterized by the motorway ring roads, and normally the four ring road is seen as the separator of the urban area, which occupies around $670 \mathrm{~km}^{2}$. The business establishments are recorded covering Beijing Municipality with 220 postcodes, allowing us to geo-code economic activities.

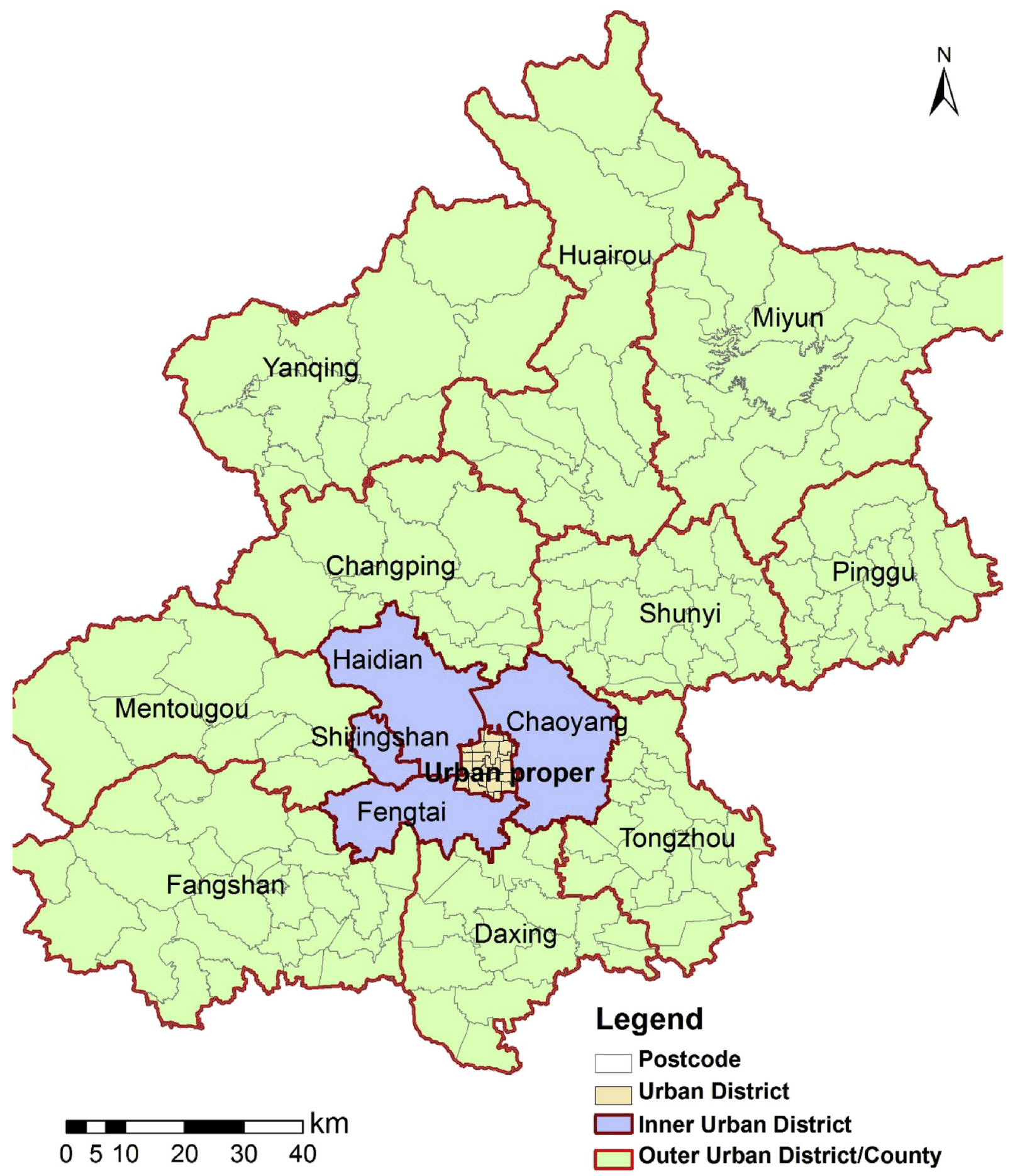

Fig. 3. Beijing spatial structure and postcodes. 
The employment data was further coded by the main business scope of the firm, according the SIC in the I-O table. A total of 328,844 records for $8,250,150$ employees were processed. It must be noticed that the net increase data, if available, would be more appropriate than gross increase. However, the dataset provides no records about expanding, breaking-down or other changes of firms. Owing to this limitation, it is hard to obtain the real-time employment for all firms in the city region. Nevertheless, the gross increase data, with five year-span, can be seen as an approximation to the pattern of employment increase in this period so that the spatial pattern of the functional relationships can be analyzed.

\subsection{Deriving industrial co-agglomeration patterns}

The industry co-agglomeration patterns were derived by the Principle Component Analysis method (PCA) of indirectly measuring Input-Output $(\mathrm{I}-\mathrm{O})$ relations of industries, in line with regional scientist Czamanski (1971) and other recent work (Akgungor, 2006; Feser \& Bergman, 2000; Funderburg \& Boarnet, 2008). By comparing other methods, Huallachain (1984) has confirmed the value of this method in detecting complementary relationships, tracing the network of interactions and revealing critical linkages in industrial subsystems (Yang, Liang, \& Cai, 2014).

Specifically, if $a_{i j}$ and $b_{i j}$ are the purchase and sale values of goods and services of sector $i$ from or to $j$, the intermediary purchase and sale coefficient $p_{i j}$ and $s_{i j}$ were calculated as $p_{i j}=a_{i j} / \sum_{j} a_{i j}$ and $s_{i j}=b_{i j} / \sum_{j} b_{i j}$. Each coefficient is an indicator of dependence between the relative linkages of industry $i$ on $j$ in terms of relative purchasing and sales. All of them respectively comprise vectors $\mathbf{p}$ and $\mathbf{s}$, representing demand and supply patterns for the industry. Each pair of industries $m$ and $n$ has demand patterns $\mathbf{p}_{m}$ and $\mathbf{p}_{n}$ and supply patterns $\mathbf{s}_{m}$ and $\mathbf{s}_{n}$. The demand and supply relationships of the two industries can be evaluated by means of correlation analysis, which yields four types of structural similarity: purchase similarity $r_{p p}$, sale similarity $r_{s s}$, purchase-sell similarity $r_{p s}$ and sellpurchase similarity $r_{s p}$ between the industries $x$ and $y$. After comparing the four values, the most important relationship can be selected as the baseline variables for PCA performance.

The PCA was performed using SPSS software. Factors were extracted by eigenvalue no less than 1 and rotated by Varimax method for facilitating interpretation. Referring to previous studies (Akgungor, 2006; Feser \& Bergman, 2000, 2005; Roepke, Adams, \& Wiseman, 1974), the variables with factor loadings not less than 0.4 were selected for determining the representation of factors (industry conglomeration patterns).

The PCA was first performed for all industries, but it was found that almost all the service industries were excluded in the component matrix owing to their low factor loadings $(<0.4)$. Given the importance of service economies, we exercise the procedure above for manufacturing and service sectors separately.

\subsection{Exploring spatial representation of industry co-agglomerations}

The spatial representation of industry co-agglomerations was investigated by the employment data described above (further aggregated according to the derived agglomeration patterns), and by using the technique of Exploratory Spatial Data Analysis. This technique discloses the spatial dependence and spatial heterogeneity from spatial variables themselves without requiring prior knowledge about the study area. One popular method of Exploratory Spatial Data Analysis is Local Indicators of Spatial Association (LISA), and specifically local Moran's I. LISA acknowledges the spatial heterogeneity which is common in internal parts of cities or regions to test whether economic activities have a random spatial distribution (Fotheringham, 1997; Fotheringham \& Brunsdon, 1999; Unwin, 1996). The local Moran's I has been widely used to examine spatial patterns of social and economic occurrences (Baumont, Ertur, \& Le Gallo, 2004; Pacheco \& Tyrrell, 2002; Yu and Wei, 2008). It shows meaningful spatial configurations for interpreting results for socioeconomic considerations. Hence, local Moran's I was selected as the indicator of choice for our analysis. A significant positive value for $I$ indicates spatial clustering of similar values (high or low), a significant negative value indicates spatial dissimilarity, and a value close to zero means that economic activities are randomly distributed (Anselin, 1995; Williams and Currid-Halkett, 2011).

For Beijing municipality with $n=220$ spatial units (postcodes), where $x_{i}$ is the observation of increase in employment for cluster $x$ in area $i$ and $\bar{x}$ is the average across units, the global Moran's $I$ is calculated as:

$I=n / \sum_{i=1}^{n} \sum_{j=1}^{n} w_{i j} \times \sum_{i=1}^{n} \sum_{j=1}^{n} w_{i j}\left(x_{i}-\bar{x}\right)\left(x_{j}-\bar{x}\right) / \sum_{i=1}^{n}\left(x_{i}-\bar{x}\right)^{2}$,

where $w_{i j}$ is the spatial weight (with $j \neq i$ ).

The local Moran's $I_{i}$ is $I_{i}=\left(x_{i}-\bar{x}\right) / c \times \sum_{j} w_{i j}\left(x_{j}-\bar{x}\right)$, with $c=\sum_{i}\left(x_{i}-\bar{x}\right)^{2} / n$.

Location similarity, representing the locations for which the values of the variable are correlated, is defined by a spatial weight matrix $\mathrm{W}$ with elements $w_{i j}$. More formally, $w_{i j}=1$ when $i$ and $j$ are neighbors or $w_{i j}=0$ otherwise. Given that spatial linkages might be citywide and the clustering of economies benefit from the urban size and market capacity, the spatial weight was measured based on distance strategy. The distance between the postcode centroids in Beijing ranges from about from $16 \mathrm{~km}$ to $100 \mathrm{~km}$, and $60 \mathrm{~km}$ is about one hour driving distance under good traffic conditions; thus $30 \mathrm{~km}, 45 \mathrm{~km}, 60 \mathrm{~km}$ and $90 \mathrm{~km}$ were selected to configure the 'neighbors'. In making these calculations, the spatial weights matrix $\mathrm{W}\left(w_{i j}\right)$ was row standardized in order to avoid scale dependence and facilitate the interpretation of the statistics (Anselin, 1995).

The computational permutation approach was chosen as the inference method (Anselin, 1995, p96). Based on the computational permutation, which yielded pseudo-significance levels $(p=0.05$ in the research), the observed statistic (Moran's $I$ ) can be judged significant or insignificant. 9,999 permutations were used here to compute the empirical distribution to avoid a great sensitivity on particular randomization (Anselin, 1995; Anselin, Bera, Florax, \& Yoon, 1996).

The global Moran's I was employed to examine overall spatial autocorrelation of given functional relationships across all geographical units. The local Moran's I cluster map (with reference to the significance map) provides four types of spatial patterns, which indicate the distribution of economic activities. The positive correlation, High-High $(\mathrm{HH})$ refers to an observation with a high value surrounded by observations with high values, and Low-Low (LL) indicates an observed low value surrounded by observations with low values. The negative correlation also indicates two potential conditions: Low-High (LH) refers to an observation with low value surrounded by observations with high values, and High-Low (HL) represents an observation with high value surrounded by low values. Assuming probabilities for creating new jobs are equal for each examined place (postcode), the patterns $\mathrm{HH}$ and $\mathrm{HL}$ indicates the main place with higher performance (against the average) and more significantly representing the area concentrated by co-agglomerated industries. 


\section{Results: industry co-agglomerations and their spatial manifestations in Beijing}

\subsection{Industrial co-agglomerations in Beijing}

The PCA derived 17 manufacturing and 7 service industry coagglomerations. Table 1 summarizes the result of the PCA and these industrial patterns for Beijing. Total explained variances reached $84.3 \%$ and $89.7 \%$ for manufacturing and services respectively. The summation of the output value exceeded the total for the city because some industries contributed to more than one cluster, for example computer services was counted in both patterns of Knowledge (IT, education, sciences and technology) and Public and Social services, reflecting the situation that the co-agglomerations in a city region may not be exclusive.

According to the results of economic output value and explained variances, the largest manufacturing co-agglomeration pattern was Machinery and Metalworking (MM). Finance and business activities had two associated patterns: Producer Services-oriented Finance and Business (PSFB), and Consumer Services-oriented Finance and Business (CSFB). The former encompassed transportation related sectors, commerce, real estate, leasing and hotel services mainly, closely related to producer services; the latter involved food services and residential services. The constituent member industries of a cluster can be identified by the component matrix.

\subsection{Spatial manifestation of the industrial co-agglomerations}

Owing to text space, only the spatial results of the key Industry co-agglomerations were shown, selected by their economic output value and the share of the information of the economic structure (explained variances). Using the global Moran's I (Table 2), the spatial test proved the hypothesis that the co-agglomeration of industries significantly concentrates in some places of the region, on the condition of different ranges of distances. Only the Petroleum pattern did not show spatial autocorrelation at a significant level at any examined distance.

Examining the jobs created by the functionally related industries, local Moran's I indicates the spatial occurrences of the concentration of industrial co-agglomerations by two forms. $\mathrm{HH}$ can be taken as the hotspots of the concentration, as the local value and surrounding values are significantly higher than the average value of the global. HL represents the island development of the concentration because the high value is isolated from the other randomization process by low values.

Fig. 4 illustrates that MM pattern concentrates in the southwest quadrant of the city, with some distributed in the north. With the increase of hinterland, with the distance from $30 \mathrm{~km}, 45 \mathrm{~km}$, to $60 \mathrm{~km}$, the MMM islands shift to the key towns of Pinggu, Huairou and Miyun. A boundary dividing the spatial pattern of the MM coagglomeration pattern was observed, with less spatial correlations in the north and an agglomerating-diffusing trend in the south.

The hotspots of ICT pattern were located in the northern part of the city, centred at ZSP (Fig. 5), and expanded with the extension of distance tested.

Figs. 6 and 7 demonstrate the area where the Petroleum and Chemical industry co-agglomerations are. Not surprisingly, the Petroleum co-agglomeration pattern was adjacent to the biggest petroleum company, Yanshan Petroleum (Fig. 6), which has over half a century of history and accommodates over 100,000 employees (Yang et al., 2013).

The PSFG squatted in the urban centre (Fig. 8). With the increase of the distance for testing the spatial interaction, the core of PSFB employment concentration expanded and the town seats of counties gradually become the hotspots. Surrounding these hotspots are the LH spatial correlation areas, embodying a high dependent relation on the city centre and county centre. The Knowledge pattern took a similar pattern, also demonstrating that the city centre and county centre are the main places for education and technology services (Fig. 9).

Given the PSFB and Knowledge concentration nearly saturated almost all the urban centre, further exploration was made to investigate at the urban level based on the distance strategy of

Table 1

PCA result and industrial clusters in 2002.

\begin{tabular}{|c|c|c|c|c|}
\hline Representation of industrial cluster & Eigenvalues & Explained information & $\%$ of manufacturing/services & $\%$ of the total \\
\hline \multicolumn{5}{|l|}{ Manufacturing } \\
\hline Machinery, metalworking and construction & 10.3 & $13.0 \%$ & $34.1 \%$ & $16.2 \%$ \\
\hline \# Machinery and metalworking & & & $22.30 \%$ & $10.60 \%$ \\
\hline ICT manufacturing & 8.6 & $10.9 \%$ & $24.3 \%$ & $11.5 \%$ \\
\hline Chemical & 6.0 & $7.5 \%$ & $5.7 \%$ & $2.7 \%$ \\
\hline Energy-supplying and construction materials & 5.9 & $7.5 \%$ & $5.6 \%$ & $2.7 \%$ \\
\hline Wearing apparel & 4.2 & $5.4 \%$ & $2.0 \%$ & $1.0 \%$ \\
\hline Wood products and sports and \& cultural goods & 4.2 & $5.3 \%$ & $1.0 \%$ & $0.5 \%$ \\
\hline Printing, paper products, beverage \& tobacco & 3.5 & $4.4 \%$ & $3.3 \%$ & $1.6 \%$ \\
\hline Steel processing & 3.3 & $4.2 \%$ & $3.4 \%$ & $1.6 \%$ \\
\hline Non-metal products & 3.1 & $4.0 \%$ & $2.5 \%$ & $1.2 \%$ \\
\hline Non-ferrous metal manufacture & 3.0 & $3.8 \%$ & $0.5 \%$ & $0.2 \%$ \\
\hline Petroleum & 2.9 & $3.6 \%$ & $11.4 \%$ & $5.4 \%$ \\
\hline Food processing & 2.8 & $3.6 \%$ & $3.3 \%$ & $1.6 \%$ \\
\hline Non-ferrous metal mining and transportation equipment & 2.3 & $2.9 \%$ & $1.0 \%$ & $0.5 \%$ \\
\hline Wood textile and art crafts & 1.9 & $2.4 \%$ & $2.0 \%$ & $0.9 \%$ \\
\hline Pharmaceutical and fertilizer & 1.7 & $2.2 \%$ & $2.9 \%$ & $1.4 \%$ \\
\hline Automobile & 1.6 & $2.0 \%$ & $3.6 \%$ & $1.7 \%$ \\
\hline Electric equipment & 1.4 & $1.8 \%$ & $2.7 \%$ & $1.3 \%$ \\
\hline \multicolumn{5}{|l|}{ Services clusters } \\
\hline Producer serviced-oriented finance and business & 14.3 & $35.7 \%$ & $58.9 \%$ & $29.6 \%$ \\
\hline Knowledge (IT, education, sciences and technology) & 5.6 & $14.0 \%$ & $30.3 \%$ & $15.2 \%$ \\
\hline Consumer serviced-oriented finance and business & 5.6 & $13.9 \%$ & $30.7 \%$ & $15.4 \%$ \\
\hline Health care, public facilities and IT & 4.3 & $10.7 \%$ & $5.0 \%$ & $2.5 \%$ \\
\hline Public and social services & 2.6 & $6.4 \%$ & $5.0 \%$ & $2.5 \%$ \\
\hline Information and cultural services & 2.1 & $5.2 \%$ & $9.8 \%$ & $4.9 \%$ \\
\hline Tourism and exhibitions & 1.5 & $3.7 \%$ & $1.0 \%$ & $0.5 \%$ \\
\hline
\end{tabular}


Table 2

Global Moran's I of identified industry co-agglomeration pattern at the municipal level.

\begin{tabular}{|c|c|c|c|c|c|c|}
\hline & & $30 \mathrm{~km}$ & $45 \mathrm{~km}$ & $60 \mathrm{~km}$ & $90 \mathrm{~km}$ & $120 \mathrm{~km}$ \\
\hline \multirow[t]{2}{*}{ MM } & Moran's I & 0.046 & 0.028 & 0.014 & 0.004 & -0.003 \\
\hline & p-value & 0.010 & 0.006 & 0.010 & 0.008 & 0.087 \\
\hline \multirow[t]{2}{*}{ ICT } & Moran's I & 0.010 & 0.012 & 0.016 & 0.003 & -0.004 \\
\hline & p-value & 0.107 & 0.037 & 0.006 & 0.013 & 0.878 \\
\hline \multirow[t]{2}{*}{ Petroleum } & Moran's I & 0.010 & 0 & -0.002 & -0.002 & -0.003 \\
\hline & p-value & 0.117 & 0.741 & 0.72 & 0.902 & 0.916 \\
\hline \multirow[t]{2}{*}{ Chemical } & Moran's I & 0.007 & 0.016 & 0.013 & -0.023 & -0.006 \\
\hline & p-value & 0.186 & 0.021 & 0.012 & 0.083 & 0.063 \\
\hline \multirow[t]{2}{*}{ PSFB } & Moran's I & 0.206 & 0.103 & 0.031 & -0.009 & -0.016 \\
\hline & p-value & 0.001 & 0.001 & 0.002 & 0.044 & 0.001 \\
\hline \multirow[t]{2}{*}{ Knowledge } & Moran's I & 0.133 & 0.064 & 0.015 & -0.007 & -0.011 \\
\hline & p-value & 0.002 & 0.004 & 0.012 & 0.178 & 0.001 \\
\hline
\end{tabular}

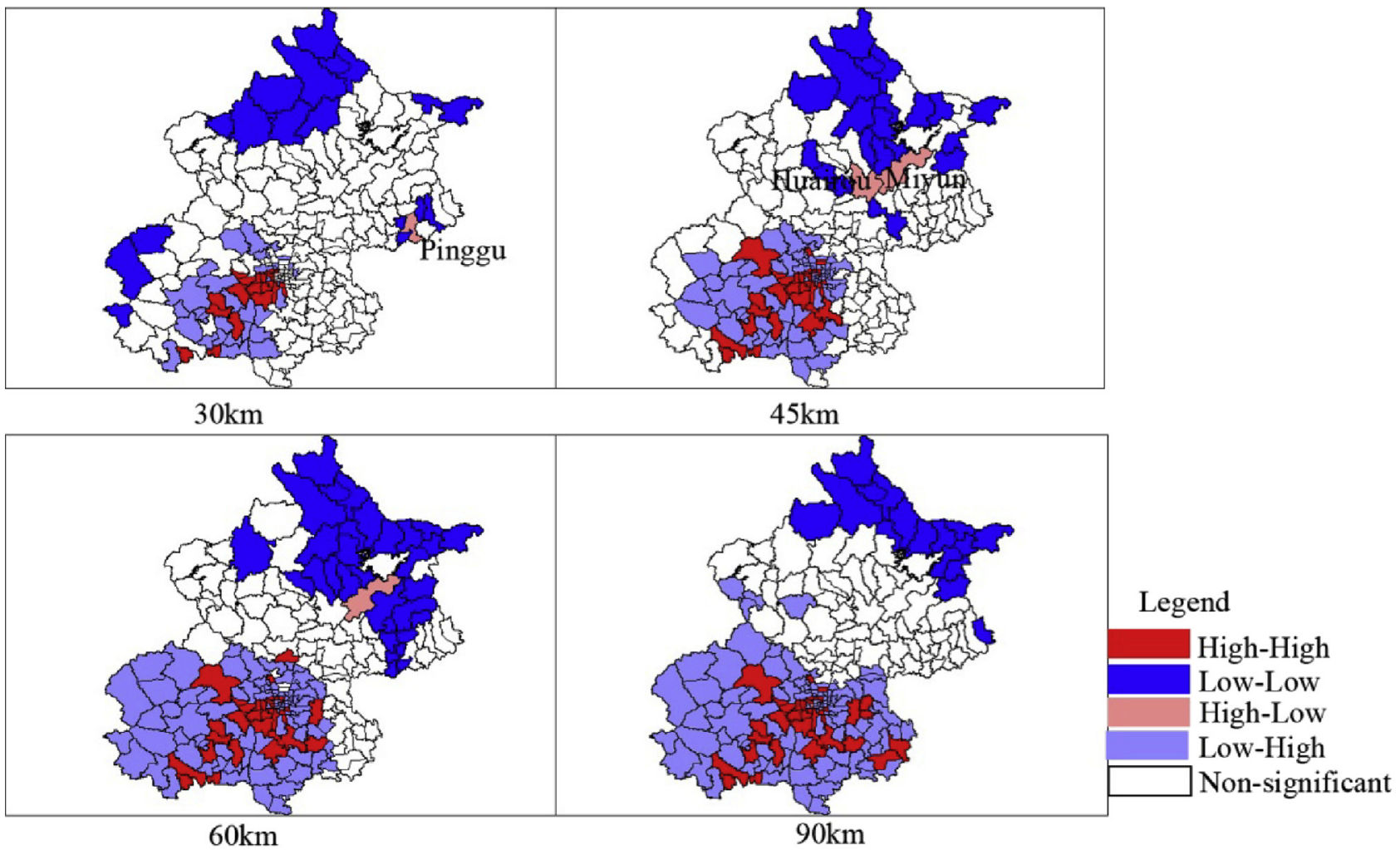

Fig. 4. The spatial manifestation of the MM pattern at the municipal level.

$30 \mathrm{~km}$ (Fig. 9). This exploration demonstrates that PSFB activities were significant in the CBD area and the Financial Street, where the headquarters of national banks are concentrated. The place for The Knowledge cluster stayed mainly in the northeast part of the city centre which is agglomerated by institutes and universities, including Chinese Academy of Sciences, Beijing and Tstinghua Universities (see Fig. 10).

\section{Discussion}

6.1. Understanding the spatial representations of industrial coagglomeration patterns

The ESDA method straightforwardly showed the frequency and location of the main places of co-agglomeration patterns. It is clear that different patterns have various prosperities of the occurrence at the city regional spaces. Some patterns likely concentrate in few places but some are in several ones. At the $30 \mathrm{~km}$ distance, the number of hot and island places of the ICT is more than that of the $\mathrm{MM}$, Petroleum and Chemical patterns. Not surprisingly, the main location of services in the urban centre and manufacturing industries are in the peri-urban or sub-urban areas. But interestingly, the ICT and Knowledge patterns can overlap places. The size of the land area for the significant economic activities sharing industrial co-agglomeration pattern is hard to discern as firms and people cannot be limited by geographical boundary. However, using postcode as a spatial conditioner, the area accommodating these activities can be roughly estimated by the postcode boundary at least.

This analysis directly links the abstract economic space and geographical space. With the co-agglomeration of industries, the function of the place is substantiated. As Figs. 3-9 show, the industrial co-agglomeration relations are projected onto several areas with higher performance of job creation, indicating specific places 

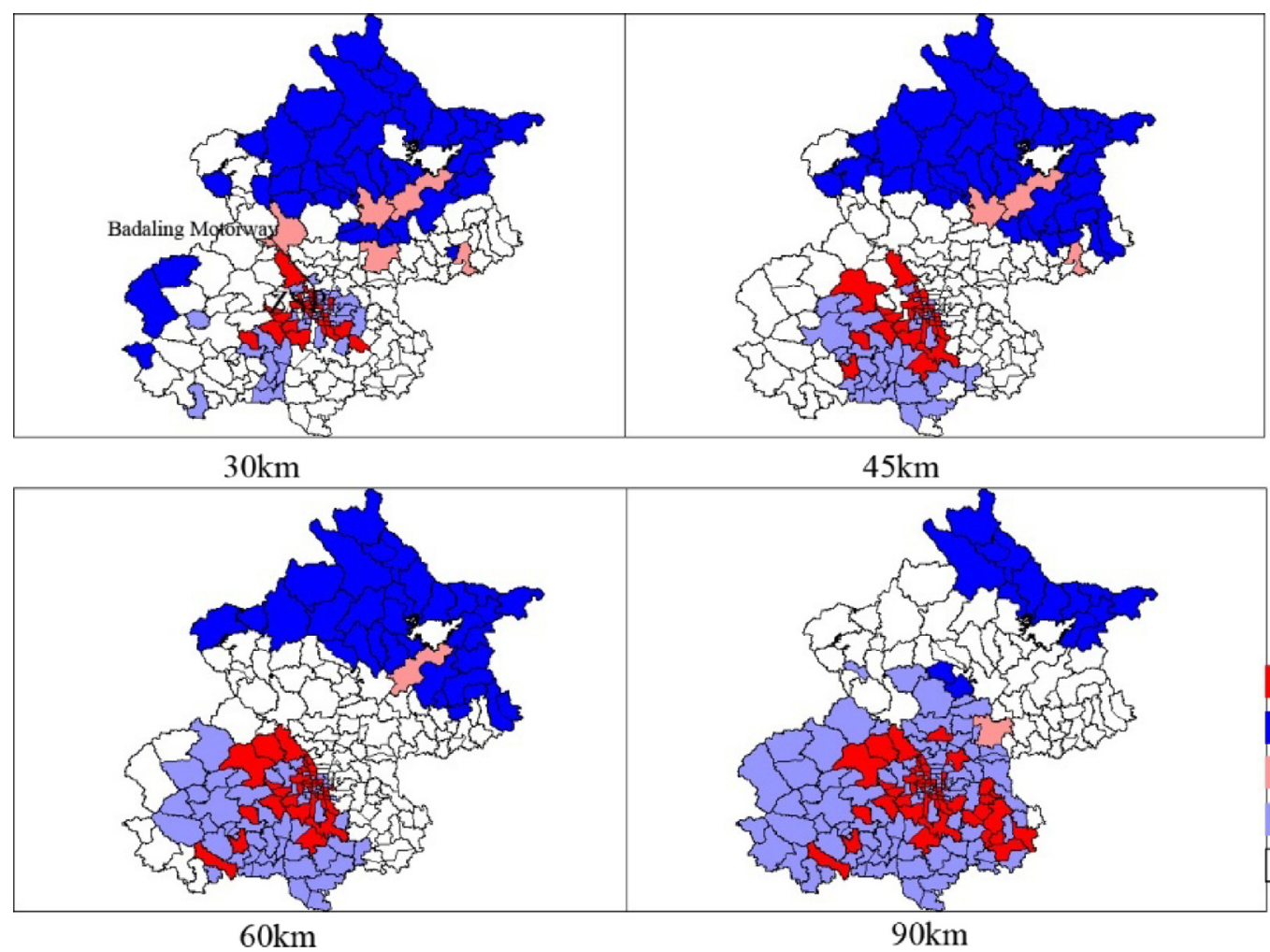

Legend

Fig. 5. The spatial manifestation of the ICT pattern at the municipal level.

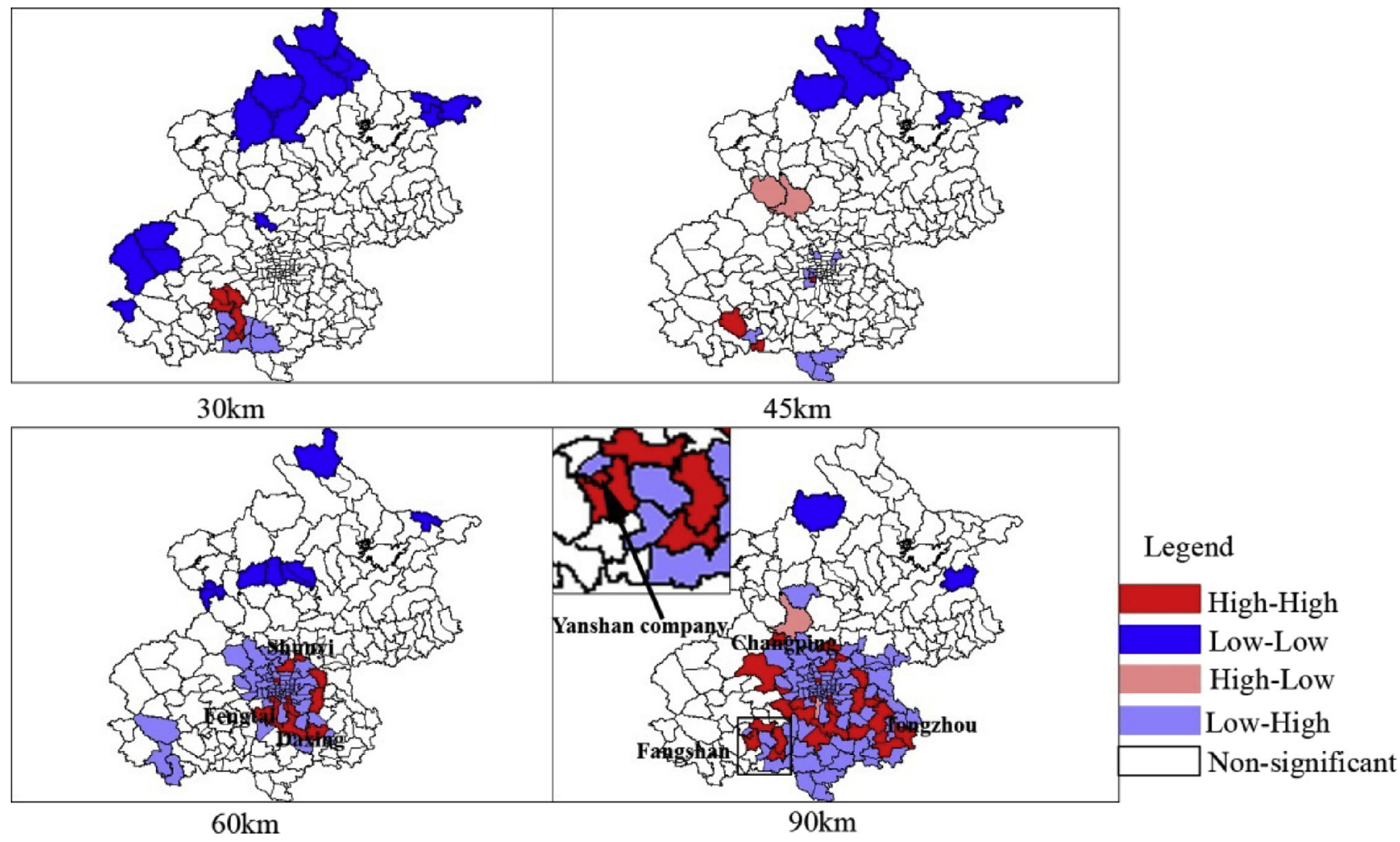

Fig. 6. The spatial manifestation of the Petroleum pattern at the municipal level.

with high possibilities to generate agglomeration economies effects. The function of the place is therefore determined, and sometimes, the one place may have several functions, as the industrial co-agglomeration pattern overlaps, or some places 


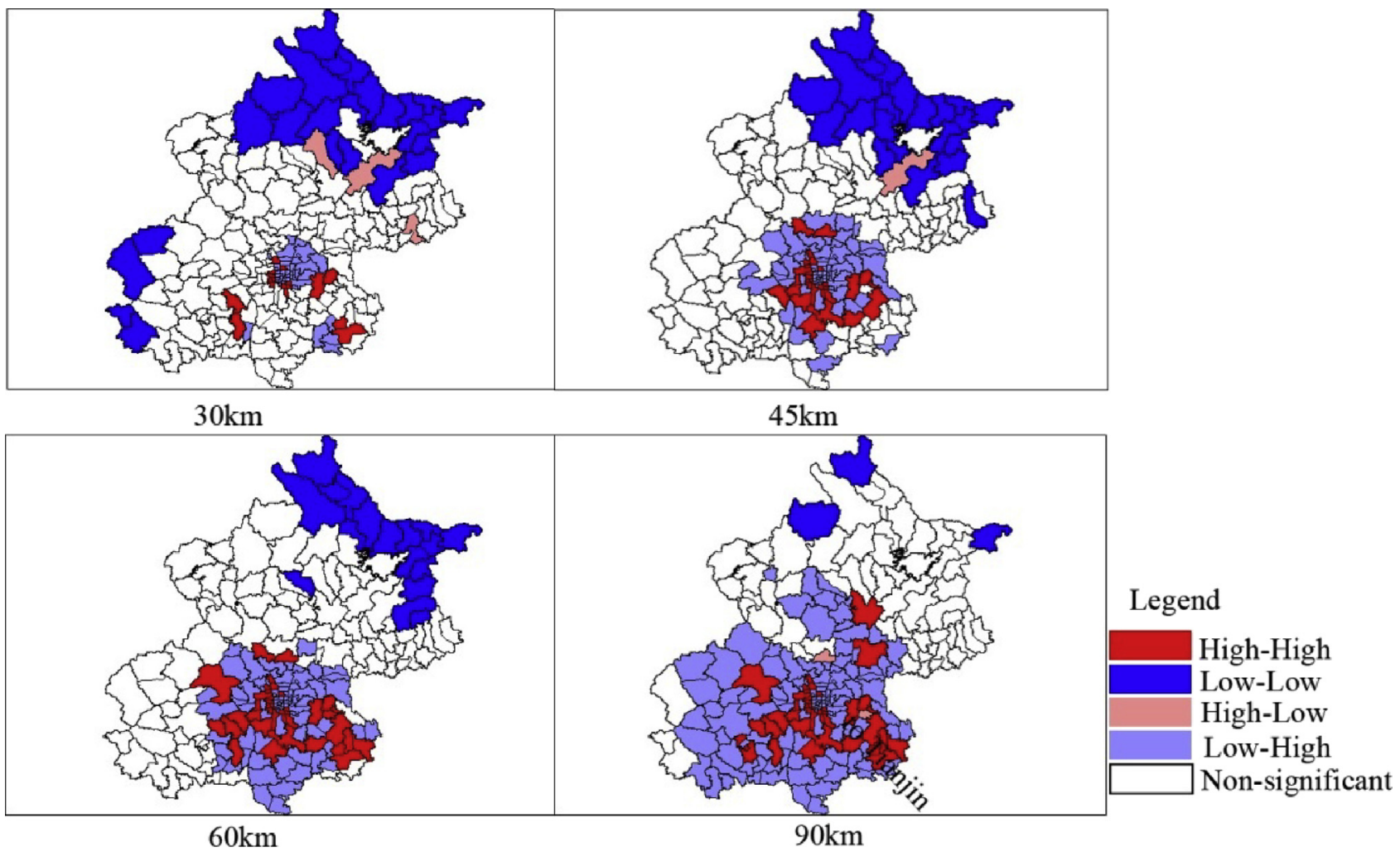

Fig. 7. The spatial manifestation of the Chemical pattern at the municipal level.

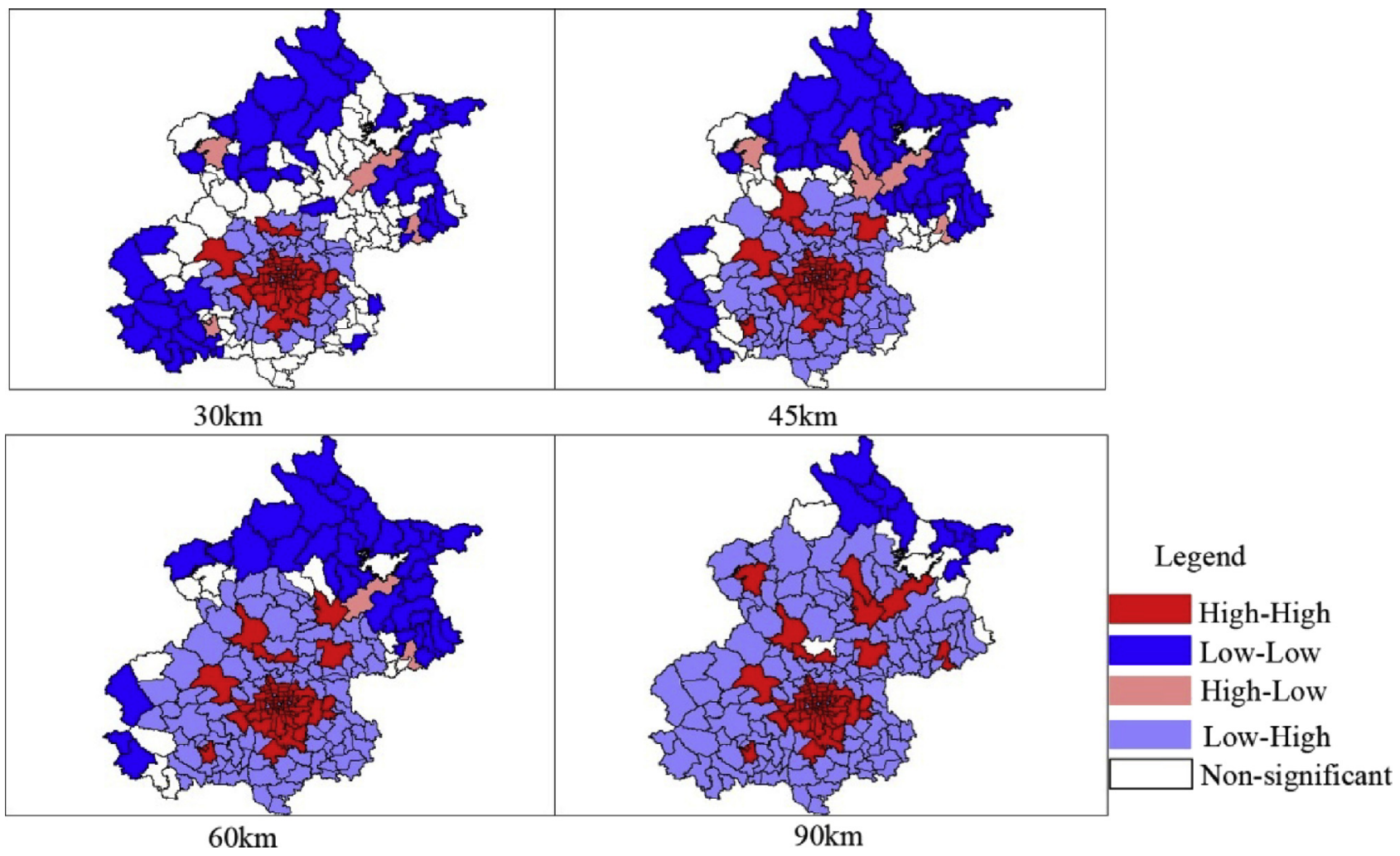

Fig. 8. The spatial manifestation of the PSFG pattern at the municipal level. 

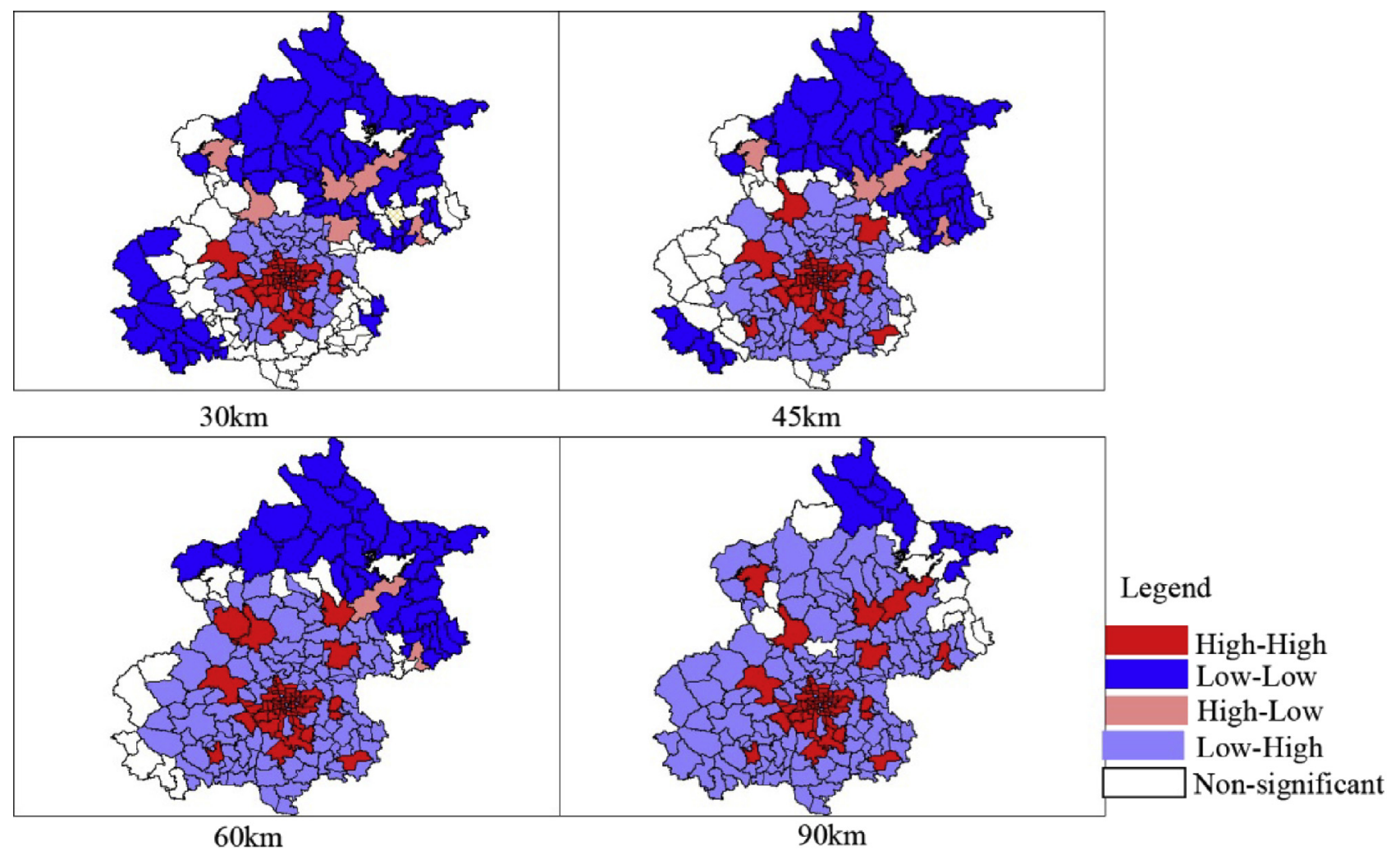

Fig. 9. The spatial manifestation of the Knowledge pattern at the municipal level.

Knowledge pattern, indicating the major function of this area is for ICT and knowledge activities. That becomes a niche for the synergy between brain power (Chinese Academy of Sciences, Tstinghua and Peking universities) and the ICT industries (Lenovo for instance) and as a return, the development of this synergy exposes the knowledge-ICT function on this area. Another case is the Chemical and Petroleum pattern. They share some of the same locations for hotspots to some extent, illustrating the corresponding relationship between economic and geographic spaces for chemical and petroleum industries. Elucidating these patterns can help inform recruitment, supply chains, and other planning components to foster not only industrial growth but also knowledge and technology investments.

Spatial hierarchy is explored by different distance devices. Within a certain range, longer distance, more areas are likely spatially correlated, because the local value is against the global average value. Some areas with $\mathrm{HH}$ or HL forms are constantly found whichever the distance is, and usually at the shortest distance measurement is robust. We may take these places as the key area with the industry pattern because their value is higher than others at any distance tested. It is interesting to note that with the distance constrain looser, other places occur at significance level. It is also noticeable that the test of the PSFB, Knowledge and ICT activities shows that at the city regional level, they are at many places; but at the urban center level, they are exactly the place where the normal knowledge tells. The ESDA method uncovers the spatial interaction with spatial weight matrix of the postcodes, and to some extent, helping understand the spatial process of economic activities.

Spacing is the distance among the place labeled by the same, similar or different functions. It helps investigate the spatial structure of the city region with a perspective of industrial development. Different patterns also have different spacing. Short spacing of the same or related function areas help the communication of economic activities such as the ICT and knowledge, and enable one place to gain easier access to the facilities of other place. In addition, the same, similar or interrelated industries are encouraged in the same or adjacent areas, the urban centre currently predominates in several functions of the ICT, Knowledge and PSFB. When these economic activities saturate the urban center space in a short distance, the spacing issue arises increasing the possibility of the pressure of the urban center and meanwhile impairing developmental opportunity of the subcenters. Recognizing the potentially detrimental effects of this saturation is key to future urban planning efforts.

\subsection{As a tool of evaluating urban planning initiatives}

The analysis above provides a way of pre-informing planners or policy makers about spatial-economic activities. Since the agglomeration economies effects come from enjoyable cooperative and competitive economic relations, but also arising from the sharing of common facilities in proximate areas, the presence of the area with high employment growth would encourage or inhibit another area as the receipt with similar economic developmental type. From a policy perspective, promoting activities in existing or adjacent areas would be much easier in terms of economic relations, business environment and facilitating costs.

This study can also be used for the ex-ante evaluation of planning initiatives. Clearly, the key areas of examined industrial coagglomeration patterns heavily squat in the urban center, which can partially explain the failure of the proposed sub-centers, which are supposed to carry certain economic functions. This underscores the importance of linking further development with up to date market patterns.

The analyzed agglomeration patterns also help understand the 


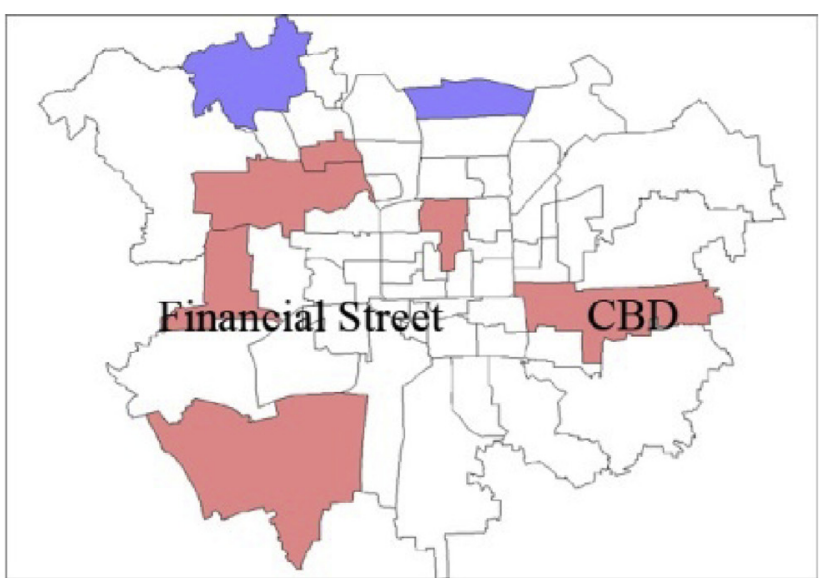

PSFB

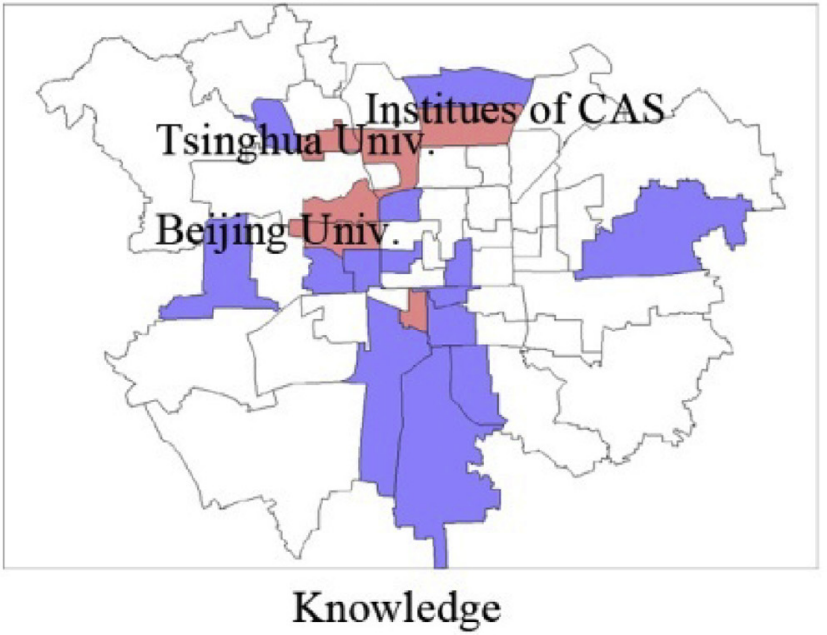

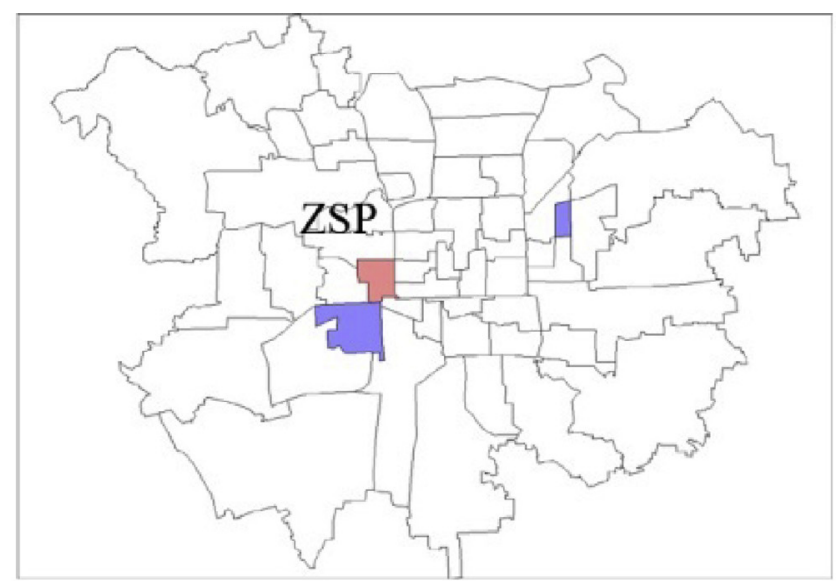

ICT

Fig. 10. The spatial manifestation of the PSFB, ICT patterns at the urban level (distance = $30 \mathrm{~km}$ ).

function of the planned various business and industrial parks. Fig. 9 clearly shows the PSFB pattern was strongly evident in the Financial Street and the CBD area. The appearance in the Financial Street is largely due to the fact that this place is concentred by the headquarters of all the main stated Chinese banks, Security Committee and Bank Committee. The CBD is planned as the major place to receive the headquarters or agencies of multinational corporations.

Table 3 indicates a comparison of the results with the planned industrial parks. Owing to the data and text limitation, only the key agglomeration patterns were used to check whether the planned economic function can be embodied by these key agglomeration patterns if they were established before 2002. Some parks were consistent with the derived key agglomeration patterns, for instance ZGC Haidian and ZGC Yizhuang Parks for the ICT pattern. The two cases indicate a rapport between the market force and policy regulations. There was also a distortion between the market force and policy regulations. The planning initiatives were totally different from the embodied industrial co-agglomeration pattern such as ZGC Changping Park and Yongle Park. The key function proposed in some parks were not realised for example ZGC Electronic Zone. That comparison can be used to check whether the planning initiatives follow the market force if they were built in or after 2002.

\subsection{Urban policy implications}

Analyzing and adjusting according to the market forces is a challenge for urban planners. This paper probes into this issue by looking at the co-agglomeration of industries, which is a fundamental mechanism of driving urban economic growth and spatial change. The findings provide evidence to explain that the subcenter plan doesn't work in Beijing, and suggest that the current industrial park scheme for promoting cluster-type development is also not without problems. It warns that planners should carefully think of the spatial structure of the city when economic activities are encouraged, taking into consideration their location, function, frequency, spatial hierarchy and spacing. With economic dynamics, some places are 'hot', some are 'cold' (marked in blue in the local cluster maps). With the changing of these hot and cold areas, city spatial structure will change correspondingly. If used appropriately, this analysis method could provide a valuable tool for city planners to balance out market forces.

In order to better understand the spatial structure associated with industrial co-agglomeration, the paper proposes the concepts of location, function, frequency, spatial hierarchy and spacing. These concepts are worthwhile to be considered when urban planning policy are made. The location and function of industrial co-agglomeration provides a clue for urban planners to leverage urban functional area and encourage multifunctional use of place. The frequency indicates the coexistence of places which are 
Table 3

Comparing the function of planned parks and the embodied agglomeration patterns.

\begin{tabular}{|c|c|c|c|c|}
\hline $\begin{array}{l}\text { Industrial or business } \\
\text { Park }\end{array}$ & $\begin{array}{l}\text { Designation } \\
\text { level }\end{array}$ & $\begin{array}{l}\text { Established } \\
\text { year }\end{array}$ & Proposed main Industries/Function & $\begin{array}{l}\text { Embodied by the co- } \\
\text { agglomeration patterns in } 2002\end{array}$ \\
\hline ZGC Park & National & & & \\
\hline ZGC Electronic Park & National & 1999 & ICT manufacturing & \\
\hline ZGC Desheng Park & National & 2002 & Hi-tech, finance and creative Industry & ICT \\
\hline ZGC Jianxiang Park & National & 2003 & ICT manufacturing, Life Industry, Exhibition & ICT \\
\hline ZGC Haidian Park & National & 1991 & ICT manufacturing & ICT \\
\hline ZGC Fengtai Park & National & 1991 & $\begin{array}{l}\text { ICT manufacturing, bio-pharmaceuticals, advanced-equipment, and new } \\
\text { materials }\end{array}$ & MM, ICT \\
\hline ZGC Changping Park & National & 1991 & Energy technology, and bio-pharmaceuticals & ICT \\
\hline ZGC Yizhuag Park & National & 1994 & ICT manufacturing & ICT \\
\hline ZGC Yonghe Park & National & 2006 & Creative industry & ICT \\
\hline ZGC Daxing Park & National & 2002 & Biopharmaceuticals & \\
\hline ZGC Shijingshan Park & National & 2006 & ICT manufacturing, digital media, and creative industry & MM, ICT, Chemical \\
\hline $\begin{array}{l}\text { Beijing Development } \\
\text { Area }\end{array}$ & National & 1992 & $\begin{array}{l}\text { Hi-tech industry first and later focusing on ICT manufacturing, } \\
\text { biopharmaceuticals, equipment manufacturing and automobile }\end{array}$ & MM*, Chemical \\
\hline $\begin{array}{l}\text { Tianzhu Export } \\
\text { Processing Zone }\end{array}$ & National & 2000 & $\begin{array}{l}\text { ICT manufacturing, biopharmaceuticals, gem processing and equipment } \\
\text { manufacturing }\end{array}$ & \\
\hline $\begin{array}{l}\text { Tianzhu Airport } \\
\text { Industrial Zone }\end{array}$ & Municipal & 1994 & ICT manufacturing and biopharmaceuticals & \\
\hline $\begin{array}{l}\text { Tongzhou Industrial } \\
\text { Development Zone }\end{array}$ & Municipal & 1992 & New materials, pharmaceuticals, telecoms, and finer chemicals & \\
\hline $\begin{array}{l}\text { Pinggu Economic } \\
\text { Development Zone }\end{array}$ & Municipal & 1992 & ICT manufacturing, electronics, chemical, food, and building materials & MM, Chemical \\
\hline Yanqi Economic Zone & Municipal & 1992 & Food, and packing & \\
\hline $\begin{array}{l}\text { Yongle Economic } \\
\text { Development Zone }\end{array}$ & Municipal & 1992 & ICT manufacturing, automobile, machinery, building material and warehouse & Chemical \\
\hline $\begin{array}{l}\text { Badaling Economic } \\
\text { Development Zone }\end{array}$ & Municipal & 1992 & Hi-tech industrial product processing & \\
\hline $\begin{array}{l}\text { Yanqing Economic } \\
\text { Development Zone }\end{array}$ & Municipal & 1992 & Biopharmaceuticals, textile, garment, and food & \\
\hline $\begin{array}{l}\text { Shunyi Linhe Industrial } \\
\text { Zone }\end{array}$ & Municipal & 1992 & Automobile, ICT manufacturing, optic fibers, and bio-pharmaceuticals & \\
\hline $\begin{array}{l}\text { Jinqiao Hi-tech Industrial } \\
\text { Base }\end{array}$ & Municipal & 2002 & Environmental and energy industry, ICT manufacturing & \\
\hline $\begin{array}{l}\text { Daxing Industrial } \\
\text { Development Zone }\end{array}$ & Municipal & 1992 & Biopharmaceuticals, software and new material & \\
\hline $\begin{array}{l}\text { Miyun Industrial } \\
\text { Development Zone }\end{array}$ & Municipal & 1992 & Food, ICT manufacturing and automobile parts & \\
\hline
\end{tabular}

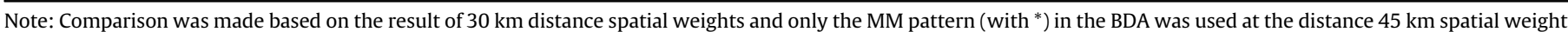

engaged in a similar and perhaps have connections of a center type of economic activities, but the number of these places is subject to the overall function of the city and its size of geographical area. Spatial hierarchy further discriminates the importance of these places, which can be a reference to elaborate the hierarchy of places in the city. Spacing is crucial to understand the reach of spillover effects of industrial co-agglomerations, and remind planners to be careful about the distance of co-agglomerated industries and ensuing potential problems such as traffic and environmental sustainability. Taken together, these factors can enable urban planners to ensure that policy regulations and market forces are not only aligned but also operate synergistically.

\section{Conclusions}

This paper contributes to regional economic growth theory by linking abstract economic and actual geographical spaces. Since industry co-agglomeration clearly contains connection to economic growth, this approach is useful to consistently find growing potentials in the both economic and geographical spheres. This study also drives closer the two important concepts of growth poles and industry clusters in urban and regional studies. Dependent on sectoral Input-Output (IO) relations, the concept of regional clusters is naturally akin to the growth poles in the abstract economic space (Sternberg, 1991, 1996). This study partially illustrates some growth poles can contain several clusters, and clusters can be growth poles propelling the process of spatial development in the city and region. It provides a way of appreciation of transmission of growth from economic to geographical space. This can help policymakers ensure alignment between market forces and urban policy regulations, in particularly with proposed concepts of location, function, frequency, spatial hierarchy and spacing to understand the spatial representation of industrial co-agglomeration pattern in geographical space. This research is not without limitations. Finer scale data, including $\mathrm{I}-\mathrm{O}$ classifications and spatial units, would allow us better approximate to the real presence of industry pattern and drive us to possibly better examine the planned initiatives, although current SIC codes and postcode used in this research are perhaps the finest level available in China. Finer scale data would also allow us to examine current urban and regional development concepts, such as the cluster analysis with a more detailed industrial classification. The planning analysis is so far limited to the year of 2002, therefore following-up analysis are required to update or monitor policy implementation. Future research may also further investigate the spatial impact of the co-agglomerations of different industries; for instance the ICT, finance and manufacturing would have differentiate influences on population growth, housing price, and traffic demands. All these are crucial for urban spatial policy.

\section{Acknowledgment}

The research is sponsored by a grant of the National Natural Science Foundation of China (No. 41371008, 41530751) and the support from Early Career Talent Program of Chinese Academy of 
Sciences 'Youth Innovation Promotion Association CAS' (2014042). The authors would also thank Prof. Henk Ottens from Utrecht University and Dr. Richard Sliuzas form University of Twente for their insightful discussions and comments.

\section{References}

Akgungor, S. (2006). Geographic concentrations in Turkey's manufacturing industry: identifying regional highpoint clusters. European Planning Studies, 14, 169-197. http://dx.doi.org/10.1080/09654310500418002.

Anselin, L. (1995). Local indicators of spatial association-LISA. Geographical Analysis, 27, 93-115.

Anselin, L., Bera, A. K., Florax, R., \& Yoon, M. J. (1996). Simple diagnostic tests for spatial dependence. Regional Science and Urban Economics, 26, 77-104.

Arbia, G., Espa, G., Giuliani, D., \& Mazzitelli, A. (2010). Detecting the existence of space-time clustering of firms. Regional Science and Urban Economics, 40, 311-323. http://dx.doi.org/10.1016/j.regsciurbeco.2009.10.004.

Arbia, G., Espa, G., \& Quah, D. (2008). A class of spatial econometric methods in the empirical analysis of clusters of firms in the space. Empirical Economics, 34, $81-103$.

Baissac, C. (2011). Brief history of SEZs and overview of policy debates, special economic zones in Africa (pp. 23-60).

Baumont, C., Ertur, C., \& Le Gallo, J. (2004). Spatial analysis of employment and population density: the case of the agglomeration of Dijon 1999. Geographical Analysis, 36, 146-176.

Belussi, F., \& Caldari, K. (2009). At the origin of the industrial district: Alfred Marshall and the Cambridge school. Cambridge Journal of Economics, 33, 335-355. http://dx.doi.org/10.1093/cje/ben041.

Bergman, E. M., \& Feser, E. J. (1999). Industrial and regional clusters: concepts and comparative applications. In S. Loveridge (Ed.), The web book of regional science.

Cheng, F., van Oort, F., Geertman, S., \& Hooimeijer, P. (2013). Science parks and the co-location of high-tech small- and medium-sized firms in China's Shenzhen. Urban Studies. http://dx.doi.org/10.1177/0042098013493020.

Czamanski, S. (1971). Some empirical evidence of the strengths of linkages between groups of related industries in urban-regional complexes. Papers in Regional Science, 27, 136-150. http://dx.doi.org/10.1111/j.1435-5597.1971.tb01508.x.

Duranton, G., \& Overman, H. G. (2005). Testing for localization using microgeographic data. Review of Economic Studies, 72, 1077-1106. http://dx.doi.org/ 10.1111/0034-6527.00362.

Duranton, G., \& Overman, H. G. (2008). Exploring the detailed location patterns of U.K. manufacturing industries using microgeographic data*. Journal of Regional Science, 48, 213-243. http://dx.doi.org/10.1111/j.1365-2966.2006.0547.x.

Duranton, G., \& Storper, M. (2006). Agglomeration and growth: a dialogue between economists and geographers. Journal of Economic Geography, 6, 1-7. http:// dx.doi.org/10.1093/jeg/lbi012.

Ellison, G., \& Glaeser, E. L. (1997). Geographic concentration in U.S. manufacturing industries: a dartboard approach. Journal of Political Economy, 105, 889-928.

Ellison, G., Glaeser, E. L., \& Kerr, W. (2007). What causes industry agglomeration? Evidence from coagglomeration patterns. Working Paper, N007-064.

Feser, E. J., \& Bergman, E. M. (2000). National Industry cluster templates: a framework for applied regional cluster analysis. Regional Studies, 34, 1-19. http://dx.doi.org/10.1080/00343400050005844.

Feser, E. Sweeney, S., \& Renski, H. (2005). A descriptive analysis of discrete US industrial complexes. Journal of Regional Science, 45, 395-419.

Fotheringham, A. S. (1997). Trends in quantitative methods I: stressing the local. Progress in Human Geography, 21, 88-96. http://dx.doi.org/10.1191/ 030913297676693207.

Fotheringham, A. S., \& Brunsdon, C. (1999). Local forms of spatial analysis. Geographical Analysis, 31, 340-358.

Frenken, K., Oort, F. V., \& Verburg, T. (2007). Related variety, unrelated variety and regional economic growth. Regional Studies, 41, 685-697.

Friedmann, J. (2005). Globalization and the emerging culture of planning. Progress in Planning, 64.

Funderburg, R. G., \& Boarnet, M. G. (2008). Agglomeration potential: the spatial scale of industry linkages in the Southern California Economy. Growth and Change, 39, 24-57. http://dx.doi.org/10.1111/j.1468-2257.2007.00404.x.

Giarratani, F., Gruver, G., \& Jackson, R. (2007). Clusters, agglomeration, and economic development potential: empirical evidence based on the advent of slab casting by U.S Steel Minimills. Economic Development Quarterly, 21, 148-164.

Hertog, P. D., Bergman, E. M., \& Remoe, S. (2001). Innovative clusters: Drivers of national innovation systems.

Hoover, E. M., \& Giarratani, F. (1999). An introduction to regional economics. In S. Loveridge (Ed.), The web book of regional science (wwwrriwvuedu regscwebhtm), Morgantown, WV.

Huallachain, B. O. (1984). The identification of industrial complexes. Annals of the Association of American Geographers, 74, 420-436. http://dx.doi.org/10.1111 j.1467-9787.1974.tb00426.x.

Isard, W. (1956). Location and space-economy: A general theory relating to industrial location, market areas, land use, trade, and urban structure (Vol. 1, p. 350). Mass: Cambridge. xix.

LaFountain, C. (2005). Where do firms locate? Testing competing models of agglomeration. Journal of Urban Economics, 58, 338-366.

Li, P.-F. (2012). Horizontal versus vertical learning: divergence and diversification of Lead firms in the Hangji Toothbrush Cluster, China. Regional Studies, 48 1227-1241. http://dx.doi.org/10.1080/00343404.2012.709610.

Li, P.-F., Bathelt, H., \& Wang, J. (2012). Network dynamics and cluster evolution: changing trajectories of the aluminium extrusion industry in Dali, China. Journal of Economic Geography, 12, 127-155. http://dx.doi.org/10.1093/jeg/lbr024.

Martin, R., \& Sunley, P. (2003). Deconstructing clusters: chaotic concept or policy panacea? Journal of Economic Geography, 3, 5-35.

McDonald, F., Huang, Q. H., Tsagdis, D., \& Tuselmann, H. J. (2007). Is there evidence to support porter-type cluster policies? Regional Studies, 41, 39-49.

Mota, J. Q., \& de Castro, L. M. (2004). Industrial agglomerations as localised networks: the case of the Portuguese injection mould industry. Environment and Planning A, 36, 263-278.

Neuman, M., \& Hull, A. (2009). The futures of the city region. Regional Studies, 43, 777-787. http://dx.doi.org/10.1080/00343400903037511.

Oosterhaven, J., Eding, G. J., \& Stelder, D. (2001). Clusters, linkages and interregional spillovers: methodology and policy implications for the two Dutch mainports and the rural North. Regional Studies, 35, 809-822.

Pacheco, A. I., \& Tyrrell, T. J. (2002). Testing spatial patterns and growth spillover effects in clusters of cities. Journal of Geographical Systems, 4, 275-285.

Porter, M. E. (1998a). Clusters and the new economics of competition. Harvard Business Review, 76, 70-79. http://dx.doi.org/10.1111/j.1471-8847.2009.00251.x. Porter, M. E. (1998b). On competition, Boston, MA.

Qiu, B. (1999). Challenges and problems for the development of high tech zones in China, review of the World Economics (in Chinese) (pp. 57-61).

Rainer, V. H., \& Chen, K. (2006). Whether or not industrial cluster: conclusions or confusions? Industrial Geographer, 4, 2-28.

Rigby, D. L., \& Essletzbichler, R. (2002). Agglomeration economies and productivity differences in US cities. Journal of Economic Geography, 2, 407-432.

Roepke, H., Adams, D., \& Wiseman, R. (1974). A new approach to the identification of industrial complexes using input-output data. Journal of Regional Science, 14, 15-29.

Song, J., Wang, E., Zhang, W., \& Peng, P. (2007). Housing suburbanization and employment spatial mismatch in Beijing. Acta Geographica Sinica, 62, 387-396.

Souza, S. S., \& Silva, E. A. (2011). Regional planning in the land reform literature: a gap to be bridged. Regional Studies, 45, 857-868. http://dx.doi.org/10.1080/ 00343400903496386.

Steinle, C., \& Schiele, H. (2002). When do industries cluster? A proposal on how to assess an industry's propensity to concentrate at a single region or nation. Research Policy, 31, 849-858.

Sternberg, E. (1991). The sectoral cluster in economic development policy: lessons from Rochester and Buffalo, New York. Economic Development Quarterly, 5 , 342-356. http://dx.doi.org/10.1177/089124249100500406.

Sternberg, R. (1996). Regional growth theories and high-tech regions. International Journal of Urban and Regional Research, 20, 519-538.

Unwin, D. J. (1996). GIS, spatial analysis and spatial statistics. Progress in Human Geography, 20, 540-551. http://dx.doi.org/10.1177/030913259602000408.

Wang, J., \& Wang, J. (1998). An analysis of new-tech agglomeration in Beijing: a new industrial district in the making. Environment \& Planning A, 30, 681-701.

Wei, X., \& Wang, J. (1993). New industrial space: Development and location of high tech development park in China, Beijing.

Williams, S., \& Currid-Halkett, E. (2011). The emergence of Los Angeles as a Fashion Hub. Urban Studies, 48, 3043-3066. http://dx.doi.org/10.1177/ 0042098010392080.

Xie, L. (2013). Sustainability implications of mass rapid transit on the built environment and human travel behavior in suburban neighborhoods. The Beijing Case Arisona State University.

Yang, Z., Cai, J., Ottens, H. F. L., \& Sliuzas, R. (2013). Beijing. Cities, 31, 491-506. http:// dx.doi.org/10.1016/j.cities.2011.07.007.

Yang, Z., Hao, P., \& Cai, J. (2015). Economic clusters: a bridge between economic and spatial policies in the case of Beijing. Cities, 42(Part B), 171-185. http://dx.doi. org/10.1016/j.cities.2014.06.005.

Yang, Z., Liang, J., \& Cai, J. (2014). Urban economic cluster template and its dynamics of Beijing, China. Chinese Geographical Science, 24, 740-750. http://dx.doi.org/ $10.1007 /$ s11769-014-0686-1.

Yu, Z., \& Tong, X. (2003). An innovative region in China: interaction between multinational corporations and local firms in a high-tech cluster in Beijing. Economic Geography, 79, 129-152.

Yu, D. L., \& Wei, Y. H. D. (2008). Spatial data analysis of regional development in Greater Beijing, China, in a GIS environment. Papers in Regional Science, 87, 97-117. 